\title{
Mental health legislation in contemporary India: the need for inter-sectoral dialogue
}

\author{
D. S. Goel
}

Consultant Psychiatrist, Southland Hospital Mental Health Services, PO Box 828, Invercargill 9812, New Zealand, email coldsgoel@hotmail.com

\begin{abstract}
$t$ is said that war is far too serious a matter to be left to the generals alone. The same could be said for the interface between law and mental health. With our narrow, and sometimes myopic, treatment-centric vision we are ill equipped to claim hegemony over the complex domain of legislation as it relates to mental health, even more so in the multicultural Indian subcontinent, where the medieval exists alongside the modern and where abject poverty jostles with ostentatious wealth:
\end{abstract}

'The mental health scene in India at the dawn of the twenty-first century is a bewildering mosaic of immense impoverishment, asymmetrical distribution of scarce resources, islands of relative prosperity intermixed with vast areas of deprivation, conflicting interests and the apparent apathy of governments and the governed alike.' (Goel et al, 2004)

\section{Interfacing the core issues}

Kala \& Kala in the July 2007 issue of International Psychiatry (vol. 4, no. 3, pp. 69-71) approach the subject of mental health legislation in India almost exclusively from the psychiatrist's perspective. This is one of three domains (the last listed below) of interaction between law and mental health:

o Capacity and civil status. In judgments of the legal validity of a transaction, for example a contract under the Indian Contract Act 1872, the state of the mind of the individual assumes relevance. Does the fact of psychiatric illness alone make a person incapable of entering into a contract, or continuing with a marriage, or retaining a job? Should the use of medical records be allowed in legal contexts to decide the civil status of an individual with mental disorder? There has been little or no input from mental health science to the normative content of legislation.

O Rights and immunities. Legislative measures like the Persons with Disabilities (Protection of Rights, Equal Opportunity and Full Participation) Act 1995 recognise the need for affirmative action in respect of persons with mental illness in view of their psychosocial and economic vulnerabilities. Included in this domain are laws which provide for diminished accountability for persons with mental illness, as illustrated by the provision for defence by reason of insanity contained in section 84 of the Indian Penal Code 1860. Although there has been some debate on revising the archaic McNaughten rule, the fate of the accused granted such immunity has received little attention and he or she could be kept in indefinite confinement. If such is the consequence of a successful defence on grounds of insanity, why seek to expand its scope?

O Care and treatment. The procedures for voluntary and involuntary treatment of mental disorders are prescribed in the Mental Health Act 1987. This is the domain Kala \& Kala (2007) focus on.

\section{Indian mental health law}

Laws generally reflect the prevailing values, attitudes, aspirations and practices in a society at any given point of time. The Indian Lunacy Act 1912 did just that. Primarily designed to protect society from the insane, while providing a modicum of protection to the latter against gross abuse, it did not significantly hinder progress and the reasons for India's under-performance in the mental health domain lie elsewhere (Goel et al, 2004). The underlying malaise affected the search for a new mental health law as well, which began way back in 1949, when the Indian Psychiatric Society (IPS) constituted a committee under the chairmanship of Major R. B. Davis for drafting an Indian Mental Health Bill. Three decades and many abortive drafts later, the Law Ministry stepped in and introduced a patchwork Mental Health Bill in the Lok Sabha (equivalent to the UK House of Commons) in 1979. After a tortuous 8-year journey through the parliamentary maze, the bill was finally passed in April 1987 and became law after receiving the President's assent. But it took another 6 years before the 1987 Act was notified for implementation, from 1 April 1993, 44 years after the work had first begun (Goel, 2004).

\section{It all began with a fire}

The tragic incident at Erwady in August 2001 - when 25 people with a mental illness died in a fire at night, while chained to pillars - evoked the ire of the Supreme Court and, armed with its interim order dated 15 October 2001, the government of India proceeded to conduct a detailed survey of the mental health scene in the country, using the same format which had failed to evoke any response from the various state governments when it was first circulated in June 2001. The survey revealed severe staff shortages in all categories of mental health personnel, as well as stark asymmetries in the regional distribution of these scarce resources. Basic psychiatric facilities were available in only 219 out of 520 districts for which information was available (out of the total 593) and, with the country producing fewer than 70 psychiatrists per year, there is little prospect of significant 
improvement in the near future (Goel et al, 2004). In such a scenario, the mere prescription of utopian staffing scales in the 1987 Act is unlikely to improve the lot of people who are mentally ill. The government's proposal to revise these unrealistic standards, unattainable in the foreseeable future, needs to be viewed in this context.

It was, however, a subsequent order of the Court, pertaining to strict implementation of the regulatory provisions of the 1987 Act in respect of private psychiatric facilities, which suddenly aroused the conscience of the Indian psychiatric fraternity. This recently evident concern for the rights and welfare of people with a mental illness is often based on a superficial reading of the law. Contrary to what has been stated by Kala \& Kala, sections 19 and 20 of the 1987 Act scrupulously avoid any reference to a psychiatrist, and an involuntary patient may be hospitalised on the basis of certificates from two medical practitioners, one of whom should be in government employ. In practice, though, a psychiatrist is likely to be involved, since admission will be to a psychiatric hospital or nursing home. This by itself does not, however, offer any additional safeguard. The most blatant abuse of the system happened with the connivance of two psychiatrists (neither of whom had ever met or examined the patient) who were subsequently indicted by the Supreme Court, which, in a historic departure from convention, functioned as a trial court, recorded oral evidence and arrived at a finding of fact (Anamika Chawla v. Metropolitan Magistrate, 1997). Considering the realities in general hospital psychiatric units within the public sector and in order to prevent such abuse and the consequent alienation of the consumers, the government has deliberately decided against disturbing the status quo.

Amid this preoccupation, a more critical issue appears to have escaped attention. If one goes strictly by the definition contained in section $2 r$ of the Act, many practising psychiatrists in India would not be deemed qualified psychiatrists, as their postgraduate degrees may not be recognised by the Medical Council of India, whereas the state governments remain arbitrarily empowered to designate any medical officer as a psychiatrist merely on the basis of 'knowledge and experience in psychiatry' (Dhanda et al, 2004).

\section{Mental health review tribunals}

Kala \& Kala have flagged an important issue which needs to be debated in depth. International experience with mental health review tribunals has been mixed. In New Zealand, for example, initially two tribunals, one for the North Island and another for the South Island, were established under its Mental Health (Compulsory Assessment and Treatment) Act 1992. The subjectivity inherent in this quasi-judicial process was reflected in wide variations in the success rates of appeals for discharge from compulsory treatment - $22 \%$ for the Southern $v .10 \%$ for the Northern tribunal - and the tribunals were eventually merged (O'Brien et al, 1995). Despite considerable investment in terms of the consultants' time, a majority (56\%) regarded the legislation as significantly flawed, $71 \%$ felt that it resulted in inappropriate discharges and most described it as 'time consuming and cumbersome' (Currier, 1997). The tribunals have been also criticised for their 'tunnel vision' and isolation from mainstream law (Petrila, 2003).
Experience in the UK does not appear to be substantially different (Perkins, 2003) and the Australian system has been criticised for tokenism (Swain, 2000). It has been suggested that the tribunals' reliance on imprecisely defined phrases such as 'lack of insight' and 'non-compliance' may be part of the problem (Diesfeld \& McKenna, 2005). The situation is perhaps best summed up by Wood (1995):

'Although the practice of psychiatry has made rapid strides over the past few decades, there is no doubt that one of the difficulties of structuring constructive systems of legal detention is the continuing uncertainty and debate on many aspects of psychiatric care and control.'

The situation is infinitely more complex in India, a federal union of autonomous states with widely varying standards of governance and populations several times those of countries like New Zealand. Creating another layer of quasi-judicial tribunals, often capriciously constituted on political rather than juristic considerations, is likely to result in a nightmarish scenario, far worse than the mainstream judicial system.

\section{Law and social engineering}

It is tempting to view law as an instrument of social engineering, but there are inherent limitations to this approach (Mukhopadhyay, 1998). This caveat is particularly relevant to the Indian situation, where the quality of implementation is the critical, and often the weakest, link. Landmark pieces of legislation, such as the Child Marriage Restraint Act 1929 and the Dowry Prohibition Act 1961, have remained ineffective, despite bipartisan political support.

Judicial activism is no panacea either, as illustrated by the litigation around section 309 of the Indian Penal Code, which categorises attempted suicide as an offence, which often arouses strong passions among liberals and mental health professionals. After holding the statute to be unconstitutional in 1994 (P. Rathinam v. Union of India, 1994), the Supreme Court was forced to do a 180-degree turn just 2 years later and restore the attempted suicide to the status of an offence (Gian Kaur v. State of Punjab, 1996), because it found that punishment for abetment of suicide (in India a number of women are pushed into taking their lives) was not possible without the act itself being an offence (Dhanda et al, 2004).

Section 377 of the Penal Code, which criminalises homosexuality, is currently under judicial review. Following an appeal filed by the Naz Foundation, a sexual rights nongovernmental organisation, the Supreme Court recently returned the Foundation's 2001 Public Interest Litigation (PIL) to the Delhi High Court, which had earlier dismissed it, for reconsideration. The final verdict on this sensitive issue is being awaited with interest, because a legislative initiative in this political minefield is unlikely.

\section{The consumer perspective}

Historically, mental health legislation in India has tended to marginalise the consumer perspective (Dhanda, 1996), despite widely shared concerns relating to the coercive component of such laws:

'Modern mental health laws confer on psychiatry a portion of the powers of the state, particularly the power to confine 
and treat people against their will and the power to determine the standards by which people are selected for confinement.' (Minkowitz, 2006)

These concerns, however, need to be balanced against wider societal interests (Wessely, 1997) and the mental agony of the affected families, poignantly articulated by an author and father whose son has schizophrenia:

'Can anyone explain to me wherein lies the value of freedom to refuse medication, go round the bend and end up detained in hospital?' (Salmon, 2006)

A detailed examination of these critical issues is outside the scope of the present communication, but they must inform any discussion of a new mental health law.

\section{Future directions}

It is no one's case that India's Mental Health Act 1987 is perfect. However, any demand for a new mental health law must be tempered with realism, keeping in mind the tortuous law-making process and weaknesses in the crucial domain of implementation, as well as the need to find a broad consensus among the many competing interests. This will require a comprehensive, multi-sectoral dialogue among the various stakeholders, led perhaps by the National Human Rights Commission. In this complex process, mental health professionals in general and psychiatrists in particular will have to give more than they get and any colonial vision of playing the traditional paternalistic role must be put to rest. Even then, the outcome is unlikely to satisfy everyone and, as Mukhopadhyay (1998) articulates this gloomy prognostication:

'it is not sensible to expect that law can ever be a potent force for change in the existing social structure: the hope of ensuring gender justice using law as an instrument of social engineering is an altogether impossible dream.'

\section{References}

Currier, G. (1997) A survey of New Zealand psychiatrists' clinical experience with the Mental Health (Compulsory Assessment and Treatment) Act of 1992. New Zealand Medical Journal, 110, 6-9.

Dhanda, A. (1996) Insanity, gender and the law. In Social Reform, Sexuality and the State (ed. P. Uberoi). Sage.
Dhanda, A., Goel, D. S. \& Chadda, R. K. (2004) Law and mental health: common concerns and varied perspectives. In Mental Health: An Indian Perspective (1946-2003) (eds S. P. Agarwal, D. S. Goel, R. N. Salhan, et al), pp. 170-185. New Delhi: Elsevier \& Directorate General of Health Services, Ministry of Health \& Family Welfare (available at http://www.mohfw.nic.in).

Diesfeld, K. \& McKenna, B. (2005) Insight and Other Puzzles: Undefined Terms in the New Zealand Mental Health Review Tribunal. A Report for the Mental Health Commission. Mental Health Commission.

Goel, D. S. (2004) Mental health legislation in India: historical review. In Mental Health: An Indian Perspective (1946-2003) (eds S. P. Agarwal, D. S. Goel, R. N. Salhan, et al), pp. 531-532. Elsevier \& Directorate General of Health Services, Ministry of Health \& Family Welfare (available at http://www.mohfw.nic.in)

Goel, D. S., Agarwal, S. P., Ichhpujani, R. L., et al (2004) Mental health 2003: the Indian scene. In Mental Health: An Indian Perspective (1946-2003) (eds S. P. Agarwal, D. S. Goel, R. N. Salhan, et al), pp. 3-24. Elsevier \& Directorate General of Health Services, Ministry of Health \& Family Welfare (available at http://www.mohfw.nic.in).

Kala, K. \& Kala, A. K. (2007) Mental health legislation in contemporary India: a critical review. International Psychiatry, 4, 69-71.

Minkowitz, T. (ed.) (2006) No-Force Advocacy by Users and Survivors of Psychiatry, pp. 11-22. Mental Health Commission.

Mukhopadhyay, S. (1998) Law as an instrument of social change: the feminist dilemma. In In the Name of Justice: Women and Law in Society (ed. S. Mukhopadhyaya), pp. 9-14. Manohar Publishers.

O'Brien, T. A., Mellsop, G. W., McDonald, K. P., et al (1995) A one year analysis of appeals made to mental health review tribunals in New Zealand. Australian and New Zealand Journal of Psychiatry, 29, 661-665.

Perkins, E. (2003) Decision-Making in Mental Health Review Tribunals. Policy Studies Institute, University of Westminister.

Petrila, J. (2003) An introduction to special jurisdiction courts. International Journal of Law and Psychiatry, 26, 3-12.

Salmon, T. (2006) My son has schizophrenia: why can't the system cope? Observer (Focus section), 19 November 2006. Available at http:// observer.guardian.co.uk/focus/story/0,1951739,00.html (last accessed 16 April 2007).

Swain, P. (2000) Admitted and detained: community members and mental health review boards. Psychiatry, Psychology and Law, 7, 79-88.

Wessely, S. (1997) The epidemiology of crime, violence and schizophrenia. British Journal of Psychiatry, 170 (Suppl. 32), 8-11.

Wood, J. (1995) The challenge of individual rights: mental health review tribunals. British Journal of Psychiatry, 166, 417-420.

Anamika Chawla v. Metropolitan Magistrate (1997) Order of the Supreme Court in Writ Petition (Crl) No 432 of 1995, dated 1 May 1997. In Mental Health: An Indian Perspective (1946-2003) (eds S. P. Agarwal, D. S. Goel, R. N. Salhan, et al), pp. 493-494. Elsevier \& Directorate General of Health Services, Ministry of Health \& Family Welfare (available at http://www.mohfw.nic.in)

Gian Kaur v. State of Punjab (1996) 2 Supreme Court Cases (SCC) 648.

P Rathinam v. Union of India (1994) 3 Supreme Court Cases (SCC) 648.

\section{Forced marriage}

\section{Kiran Rele MBBS DPM DNB (Psychiatry) MRCPsych}

Specialist Registrar in General Adult Psychiatry, Intensive Treatment Service, Longley Centre, Norwood Grange Drive, Sheffield S5 7JT, UK, email Kiran.Rele@SCT.NHS.UK

\begin{abstract}
his his article examines factors that are salient to understanding forced marriages and provides an overview of the issue. It aims to promote awareness in the UK, where there is a need for services to develop appropriate
\end{abstract}

responses, as primary care and the local psychiatric services are not geared up to tackle such transcultural issues.

Forced marriage is an abuse of human rights. Forced marriage occurs within diverse cultures, traditions, 